ENTREPRENEURSHIP AND SUSTAINABILITY ISSUES

ISSN 2345-0282 (online) http://jssidoi.org/jesi/

2019 Volume 6 Number 4 (June)

http://doi.org/10.9770/jesi.2019.6.4(29)

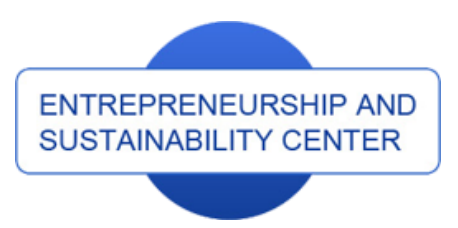

Publisher

http://jssidoi.org/esc/home

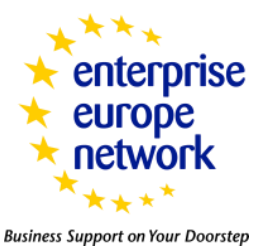

CASPA

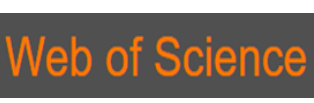

1) Clarivate

\title{
CAUSES OF NON-PERFORMING LOANS: THE EXPERIENCE OF GULF COOPERATION COUNCIL COUNTRIES
}

\author{
Mohammad Omar Farooq ${ }^{1}$, Mohamed Sayed Abou Elseoud ${ }^{2}$ \\ Seref Turen ${ }^{3}$, Mohamed Abdulla ${ }^{4}$ \\ 1,3,4 University of Bahrain, P.O. Box 32038, Sakhir, Kingdom of Bahrain \\ 2University of Bahrain and Sadat Academy for Management sciences in Egypt, Maadi, Cairo, Egypt \\ E-mails: ${ }^{1}$ farooqm59@gmail.com; ${ }^{2}$ msayed@uob.edu.bh; ${ }^{3}$ sturen@uob.edu.bh; ${ }^{4}$ maamohammed@uob.edu.bh
}

Received 16 February 2019; accepted 19 May 2019; published 30 June 2019

\begin{abstract}
As financial intermediaries and provider of financial services, banking sector plays a pivotal role in the development of any economy. Performance of loans in banks' portfolios is a critical issue for this sector. The purpose of this study is to examine the determinants of Non-Performing Loans in Gulf Cooperation Council region. This study investigates the significant factors determining the Non-Performing Loans in banking sector of this region taking into consideration bank specific as well as macroeconomic factors. Two step Generalized Method of Moments approach to study the relationship among the variables was used to examine the determinants of NonPerforming Loans in this region for a period from 2009 to 2015. Four different models employed as a result of the examination of the theories were used to observe and analyse the determinants of these non-performing loans. According to the findings of the model generated from the bad management hypothesis, Non-performing loans are a serious issue requiring due attention, and bank profitability measured by Return on Average Assets has significant and negative effect on Non-Performing Loans. This suggests that banks in this region have more incentive to increase return by using their assets and effectively managing the funds contributed by the shareholders respectively.
\end{abstract}

Keywords: Non-performing loans; GCC banking sector; Financial Stability

Reference to this paper should be made as follows: Farooq, M.O.; Elsoud, M.S.A., Turen, S.; Abdulla, M. 2019. Causes of NonPerforming Loans: The Experience of Gulf Cooperation Council Countries, Entrepreneurship and Sustainability Issues 6(4): $1955-1974$. http://doi.org/10.9770/jesi.2019.6.4(29)

JEL Classifications: G21, E44

\section{Introduction}

The banking sector plays an important role in the development of economy as they take deposits and lend to others. Banks give loans not only to individuals but to various sectors such as business and government which undertake investment and development activities. Therefore, the stability of the banking sector is an important issue of concern. 


\section{ENTREPRENEURSHIP AND SUSTAINABILITY ISSUES}

ISSN 2345-0282 (online) http://jssidoi.org/jesi/

2019 Volume 6 Number 4 (June)

http://doi.org/10.9770/jesi.2019.6.4(..)

Banks have become very cautious in granting loans and advances because failure of repayment of loans on time as per the loan agreement or contract gives rise to a serious problem of non-performing loans (NPLs), or bad loans, which in turn affects the asset quality of the banks as major part of the banks' assets is comprised of loans. The decline in asset quality due to increase in NPLs leads to bank failure and thereby affecting the financial stability of the economy.

Although definition of NPLs for various countries may differ, according to IMF Compilation Guide of Financial Soundness Indicators, "non-performing loans are those whose repayments are past due for 90 days or more" (IMF, 2005).

Stability of the banks is a major concern because banks play a crucial role in the development of economy by mobilizing funds and hence bringing stability in the economy. Therefore, banks are required to have quality assets which helps them achieve better performance. Failure to establish banking stability commonly leads to crisis.

The global financial crisis of 2008 is illustrative of how bank instability can lead to the ruin of many financial institutions. Subsequently, Central banks have established financial stability units which are responsible to prepare financial stability reports (FSR) and notify about risks to the financial system.

Banking sector faces many significant challenges and hence come across many types of risks; one of them is counterparty risk which arises due to untimely repayment of loans by borrowers leading to NPLs. Rising NPLs can become a threat to the banking system. Consequently, it will become difficult for banks to repay the deposits on time.

Moreover, lending is the key role and major source of revenue for commercial banks, and thus the non-payment of the loans affects and damages the financial position of banks which in turn affects the banks' operations as these unrecoverable loans will be written off as non-performing thereafter. In short, NPLs are a drag for any bank, negatively affecting banks' profitability and undermining depositors' confidence.

There was evidence that banking crisis in East Asian countries were due to increasing number of NPLs in banks' loan portfolio. Therefore, there is a strong need for addressing the issue of NPLs by identifying and mitigating its causes. Causes of NPLs in different countries can vary due to different economic conditions.

Since financial institutions are instrumental for a country's economic growth and development, after 2008 crisis this issue has gained increased attention and relevant research has grown substantially. According to DemirgüçKunt and Huizinga (1999), there is statistically significant difference on interest margin and bank profitability between developing and industrial countries due to several institutional factors, such as indexes of credit rights, law and order, competitiveness, corruption, and differences in financial structure. In this case, it is reported that interest margin and bank profitability are higher in developing countries than industrial countries.

Many studies were carried out indicating different determinants of NPLs. The results of those studies were inconsistent which might be due to different methods of data analysis used and different economic condition of the countries. Thereby parallel to studies on determinants of NPLs globally, it's important to study the case of focused work, as in this paper, on the banking sector of Gulf Cooperation Council (GCC) region, comprising six countries: Bahrain, Kuwait, Oman, Qatar, Saudi Arabia and United Arab Emirates.

The development and expansion of the economies of GCC countries has led to quick development of financial sector which has resulted in very high rate of growth in supplying credit to the customers. The determinants of NPLs can be different for the banks operating in the GCC due to different economic, social and political conditions, which is important for enhancing the quality of assets and the deterioration in bank assets quality and to prevent bank failure. That is the purpose of this paper focused on the banking sector in GCC. 


\section{ENTREPRENEURSHIP AND SUSTAINABILITY ISSUES}

ISSN 2345-0282 (online) http://jssidoi.org/jesi/

2019 Volume 6 Number 4 (June)

http://doi.org/10.9770/jesi.2019.6.4(..)

\section{Literature Review}

The importance of banking system and financial stability in the development of an economy is well-recognized. Stable banking system is indispensable for facilitating economic development.

Financial institutions provide funds and help industries to carry out projects in economy as well as support investment activities. Banks face many risks while granting loans; one of the risks is the default risk due to nonpayment of the loans which results in NPLs. High levels of NPLs adversely affect the asset quality, subsequently affecting the performance of the banks. This leads to financial loss of the banks and thereby affecting the financial stability of the economy. To bring about the stability, banks are required to have quality assets for better performance.

Banking system stability is being impacted by both internal factors i.e. bank specific and external factors i.e. macroeconomic (Ashraf et al. 2018; Masood et al. 2019). It is very important for policy makers and regulators to understand the drivers of high level of NPLs in the banks in order to come up with preventive measures. The management should also have good understanding of NPLs to help allocate resources efficiently. Forecasting and stress testing undertaken by bank management can be made better if research is based on identification of specific factors playing important role in increasing the level of NPLs.

Several studies done in different countries by researchers such as Salas and Saurina (2002), Williams (2004), Messai and Jouini (2013), etc., have identified the following factors as determinants of NPLs: inflation rate, unemployment, level of GDP, ROA, ROE, liquidity, capital adequacy, bank size, volume of deposits and interest rates..

Bank profitability is affected by NPLs as they influence revenues as well as expenses. High level of NPLs means it's not performing and not bringing the interest income and hence low profit. Moreover, high NPLs leads to high provisions as well as high expenses involved in recovery process like administrative costs etc., hence reducing profit.

Low profit due to high NPLs leads to low retained earnings which influences capital adequacy ratio unfavourably. As NPLs are part of total assets, the risk connected with them leads to increase in total risk weighted assets which in turn lowers the capital adequacy ratio if the capital funds remain the same.

Low profit due to NPLs also reduces cash inflows giving rise to liquidity problem. This affects banks' ability in expanding loan portfolio. At the macroeconomic level, banks' reluctance to grant loans leads to credit contraction in the economy.

High NPLs indicates weakness in the bank asset quality. Investors perceive such assets to be of high risk and hence this generally brings down stock prices of the banks. Financial performance of the banks can decrease due to NPLs' adverse effects on interest income, high expenses, high provisioning requirement and difficulty in raising funds from the market. All this will influence share prices of the banks. Furthermore, if the banks whose asset quality is weak are helped by the government through capital infusion, this may also deteriorate fiscal position of the government. Thus, rising level of NPLs raises fear and high concern for not recovering the credit on time; therefore it is important to know about the causes and determinants which give rise to NPLs.

Studies to deal with these aspects with a focus on GCC countries is relevant because of the robust development and expansion of economies of countries in this region as well as the development and expansion of Islamic banks facilitating credit expansion. Previous researches on this topic show inconsistent results due to different causes of NPLs in different countries under different economic conditions. As far as GCC is concerned, not many studies on NPLs have been conducted.

In the recent past, NPLs have received greater attention. Poor management of the loans and cost control give rise to NPLs as discussed by Berger and DeYoung (1997). Many banks are not able to generate profits due to these 


\section{ENTREPRENEURSHIP AND SUSTAINABILITY ISSUES}

ISSN 2345-0282 (online) http://jssidoi.org/jesi/

2019 Volume 6 Number 4 (June)

http://doi.org/10.9770/jesi.2019.6.4(..)

bad loans and thus risk their survival. Not only profitability but also liquidity, which is important for overall efficiency of banks, is affected by NPLs. Tesfaye (2012) stated that mismatch between maturities of asset and liability give rise to liquidity risk.

Many studies have been done before to know about the factors affecting the loan quality. Bank loans specifically NPLs were studied because of its importance in failure of banks. Some studies were done on single countries while others took into account group of countries. Whereas some studies only considered bank level factors while others only macro level factors. Below we provide a review of more specific aspects of the literature review.

\subsection{Bank Specific Factors}

A number of studies demonstrated that micro level factors that are the bank specific factors are significant in influencing the NPLs:

Berger and DeYoung (1997) did research on commercial banks in the US for the period from 1985 to 1994 and proposed the following:

1. Bad luck hypothesis: higher operating costs lead to higher NPLs as more cost is associated with administering and monitoring bad loans as well as collateral recognition.

2. Bad management hypothesis: low operational efficiency because of poor credit monitoring give rise to NPLs.

3. Skimping Hypothesis: less cost can make the bank look cost efficient in the short run and can give rise to high NPLs in future.

4. Moral Hazard Incentives: Moral hazard is more likely to occur in the banks with low capital. This increases risks in loan portfolio and therefore increases NPLs.

Profitability is a key bank specific factor of NPLs. Return on assets, return on equity and net interest margin are assumed to be negatively related to NPLs. Godlewski (2005), Louzis et al. (2012) and Klein (2013) stated that the profitability of a bank has a negative impact on NPLs. However, it is expected that profit-maximizing policies will give rise to higher risk which may induce high NPLs.

According to Makri et al. (2014), who did a study on Eurozone banking system for a period 2000 to 2008, found out that ROA did not have significant effect on NPLs which was in contrast to Boudriga et al. (2009) who did a study in MENA region on problematic loans and observed that ROA has significant negative impact on NPLs.

The inefficiency of a bank is also an important bank-specific factor of NPLs. Berger and DeYoung (1997) expressed that inefficiency leads to higher NPLs because of poor monitoring of loans, cost control and also poor loan underwriting. Likewise, Williams (2004), Espinoza and Prasad (2010), Louzis et al. (2012), Aktan et al. (2018), Fakhry et al. (2018) also found supportive results.

Rossi, Schwaiger, and Winkler (2005) did research for the period from 1995 to 2002 on east and central European countries and stated that low efficiency can be associated with uncontrollable external factors.

Not much literature is available regarding the effect of the recent financial crisis. Dietrich and Wanzenried (2011) examined bank profitability of commercial banks in Switzerland for the period from 1999 to 2009 and found that loan loss provision did not significantly affect the performance of the bank before crisis, even though loan loss provisions increased during crisis.

According to Ezeoha (2011) who did study on banks in Nigeria reported that liquidity and equity capital made the asset quality worse whereas profitability, credit expansion improved the performance of banks.

Ahmad and Ariff (2007) expressed that NPLs and regulatory capital have positive relationship; hence banks should increase capital as a cushion against potential losses due to increase in credit risk. 


\section{ENTREPRENEURSHIP AND SUSTAINABILITY ISSUES}

ISSN 2345-0282 (online) http://jssidoi.org/jesi/

2019 Volume 6 Number 4 (June)

http://doi.org/10.9770/jesi.2019.6.4(..)

Salas and Saurina (2002) and Louzis et al. (2012) found a negative relationship between bank size and NPLs and stated that bigger size of the bank enables more diversification opportunities.

Bank ownership is yet another important determinant of NPLs. Zribi and Boujelbene (2011) expressed that state banks have higher NPLs because they may have to finance the risky projects.

\subsection{Macro Level Factors}

Some studies were done in order to understand changes in asset quality due to NPLs taking into consideration the macro-economic factors.

The real GDP is one of the key factors of NPLs and it is expected to be negatively related to NPLs. Dash and Kabra (2010), Bofondi and Ropele (2011), Klein (2013) and Jiménez et al. (2006), stated a negative relationship between GDP and NPLs. However, there are some studies that show a positive relationship between GDP and NPLs such as the one conducted by Saba et al. (2012) as cited by Islamoğlu (2015) and Demirgüç and Huizinga (1999) who determined that real GDP per capital had positive and significant relationship with NPLs.

Bock and Demyanets (2012) stated that NPLs affect the economy by slowing economic growth. Similarly, Jiménez et al. (2006) did a study and determined that in the period of economic expansion, companies earn high profits and also people have more income which leads to low level of NPLs. They also stated that NPLs affect profitability and capital adequacy of the banks negatively which in turn affect lending ability of banks. Therefore, the tightening of bank credit will decrease the investments in the economy.

Bofondi and Ropele's (2011) research on Italy and Saba's et al. (2012) research on US banking sector found that lending rate has negative relationship with NPLs.

According to Klein (2013) NPLs increase unemployment rate which is in contrast with Bofondi and Ropele (2011) who expressed that unemployment rate has negative effect on bank loan quality.

Amediku (2006) as cited by Alhassan, et al. (2014) did a study on banks in Ghana and used data from the year 1995 to 2005 . He found out that nonperforming loans increased due to inflation.

In the same way, Saba et al. (2012) as cited by Islamoğlu (2015) did research on US banking sector to find out the determinants of non-performing loans. It was noted that inflation had positively significant effect with NPLs. Likewise, Klein (2013) expressed that inflation is positively related to NPLs.

Abid et al. (2014) did research and found that lower inflation rate has a positive influence on the financial conditions of debtors and eventually on the repayment of loans showing positive relationship between the inflation rate and NPLs.

According to Salas and Saurina (2002) and Jiménez et al. (2006), when there is a slowdown in the economy, NPLs will increase when unemployment rate rises and borrowers face difficulties in repaying the debt.

Amediku (2006) reported that in an economic boom as unemployment decreases, the real wages increase and so the purchasing power of households also increases, resulting in increase of the consumer demand and thereby increasing the need for credit.

Bock and Demyanets (2012) stated that high NPLs lead to exchange rate depreciation. Klein (2013) also determined that NPLs result in depreciation of exchange rate. Furthermore, Chaibi and Ftiti (2015) asserted that depreciation of the local currency may result in higher NPLs.

Moreover, many cross-country studies were also done. For example, study done in emerging market economies by Bock and Demyanets (2012) and GCC countries by Espinoza and Prasad (2010). Besides, specific countries studies were done such as the one by Quagliariello (2007) who did research on banks in Italy. 


\section{ENTREPRENEURSHIP AND SUSTAINABILITY ISSUES}

ISSN 2345-0282 (online) http://jssidoi.org/jesi/

2019 Volume 6 Number 4 (June)

http://doi.org/10.9770/jesi.2019.6.4(..)

Hoggarth et al's (2005) work as cited by Quagliariello (2007) examined loan quality of UK banks using stress test and VAR technique and discovered that inflation rate and interest rates affect adversely the asset quality of banks by taking into account loan losses.

Quagliariello's (2007) research on Italian banks found that quality of bank loans deteriorates highly during recession period, while it improves during expansion.

Gerlach et al. (2005) did a study on Hong Kong in order to explain the trends of NPL ratio using regression analysis and found that NPL ratio increases with increase in nominal interest rates but decreases with higher CPI inflation, property price inflation and economic growth.

As cited by Vatansever and Hepşen (2013), Jakubik's (2007) research found that in Czech's corporate sector, NPL rate was positively affected by increase in real exchange rate, loan to GDP ratio, interest rate and unemployment rate.

Abid et al. (2014) did a study on Tunisian banks over a period from 2003 to 2012 and determined that household's NPLs are not only affected by macroeconomic factors such as GDP, interest rate and inflation rate but also by bad management quality.

Demirgüç and Huizinga (1999) found a positive relationship between GDP growth, inflation and bank performance, whereas negative between tax burden and performance.

\subsection{Combined Factors}

There were some studies done which included both internal and external factors in order to have broad understanding of NPLs. Most of the studies used macro-economic factors as control variables.

Salas and Saurina (2002) did a study on banks in Spain. They investigated the determinants of NPLs for two types of banks, savings and commercial, and found that for savings banks GDP, inefficiency, non-collateralized loans, net interest margins affected the NPLs. Whereas for commercial banks, other factors affected NPLs like bank size, capital ratio and branch expansion, they concluded that micro factors, i.e. bank level factors, were significantly influencing factors for savings banks.

Quagliariello (2007) did a study on 200 banks in Italy for the period from 1985 to 2002 and concluded that internal factors such as efficiency, riskiness (interest income to total assets), slow credit growth and also external factors such as GDP, interest rates effects NPLs and loan provisioning.

Espinoza and Prasad (2010) investigated 80 banks in GCC countries for the period from 1995 to 2008 and concluded that non-oil GDP growth decreases NPL, whereas interest rate and risk aversion due to tight global financial situation increases NPL. They also discovered that capital size, credit growth and efficiency also impact NPL.

Klein (2013) investigated the causes of NPLs and found out excessive lending, profitability, bank equity, inflation, and unemployment affect NPLs.

Salas and Saurina (2002) did research in banks in Spain and investigated that economic growth, bank size, efficiency, interest spreads are the major factors affecting the problem loans.

Louzis et al. (2010) did a study on determinants of non-performing loans in Greek financial sector and found out that ROA, ROE and real GDP had negative whereas inflation rate, lending rate and unemployment had positive significant effect and capital adequacy ratio and loan to deposit ratio had insignificant effect on NPLs.

Swamy (2012) studied determinants of NPLs in Indian banking sector and found capital adequacy, GDP growth rate, inflation and lending rate have insignificant effect. 
ENTREPRENEURSHIP AND SUSTAINABILITY ISSUES

ISSN 2345-0282 (online) http://jssidoi.org/jesi/

2019 Volume 6 Number 4 (June)

http://doi.org/10.9770/jesi.2019.6.4(..)

Messai and Jouini (2013) did a study on 85 banks in Greece, Italy and Spain for a period from 2004 to 2008 and observed that problematic loans vary negatively with ROA, growth rate of GDP and positively with real interest rate, unemployment rate and loan loss reserves to total loans.

Dhar and Bakshi (2015) did a research on Indian public banking sector for the period from 2001 to 2005 and found that net interest margin and capital adequacy ratio have negative significant effect on gross non-performing advances (GNPA), while sensitive sector comprised of commodity, capital market and commercial real estate have a statistically positive significant impact on GNPA.

Ali and Daly (2010) studied the impact of aggregate defaults on capital stock of the bank in USA and Australia and reported that US economy is more vulnerable to adverse effects of macroeconomic shocks and NPL ratio is positively related to sovereign debt.

\section{Preliminary Analysis: NPLs Trends in GCC Countries}

The banks in the GCC countries have become more vulnerable to varying degrees due to global crisis (Espinoza and Prasad, 2010). They had experienced significant credit expansion before 2008. The favourable macroeconomic factors also played a role in credit creation and lower levels of NPLs. But in the year 2009, a sharp increase was noticed in NPLs and credit grant slowed down. NPLs previously had reached very high levels in the GCC as well. This raised concern that the recovery of outstanding loan will be difficult and therefore this draws attention towards a thorough investigation for the factors that affect NPLs in these countries.

Based on Bankscope database covering around 75 banks, the following table presents the summary statistics of NPL ratio and it can be noticed that NPL ratio in GCC countries has increased after the global crises and this could adversely affect the credit risk.

Table 1. The summary statistics of NPLs in GCC Countries

\begin{tabular}{lrrrrrr}
\hline & Bahrain & KSA & Kuwait & Oman & UAE & Qatar \\
\hline No. of banks & 15 & 11 & 11 & 7 & 20 & 11 \\
NPL ratio in 2000-2007 (average) & 5.96 & 2.93 & 3.83 & 11.35 & 4.68 & 4.58 \\
NPL ratio in 2008 (average) & 5.16 & 1.36 & 4.1 & 6.55 & 2.42 & 2.45 \\
NPL ratio in 2009 (average) & 6.07 & 2.61 & 3.96 & 7.26 & 4.75 & 4.68 \\
NPL ratio in 2015 (average) & 6.45 & 2.62 & 4.00 & 6.70 & 5.00 & 4.69 \\
\hline
\end{tabular}

Source: Bankscope Database

As can be seen from the figure 1 given below that the NPL ratio of commercial banks in Bahrain was quite high in early 2000s. Slowly and gradually it decreased. However it again increased during financial crisis which started in USA due to the collapse of subprime mortgage market in year 2007. The NPL ratio started to fall in 2010 and 2011 on average. But it increased again in 2012. It declined in the year 2013 and again rose in 2014. While in 2015, NPL ratio for most of the banks did not decrease much. 


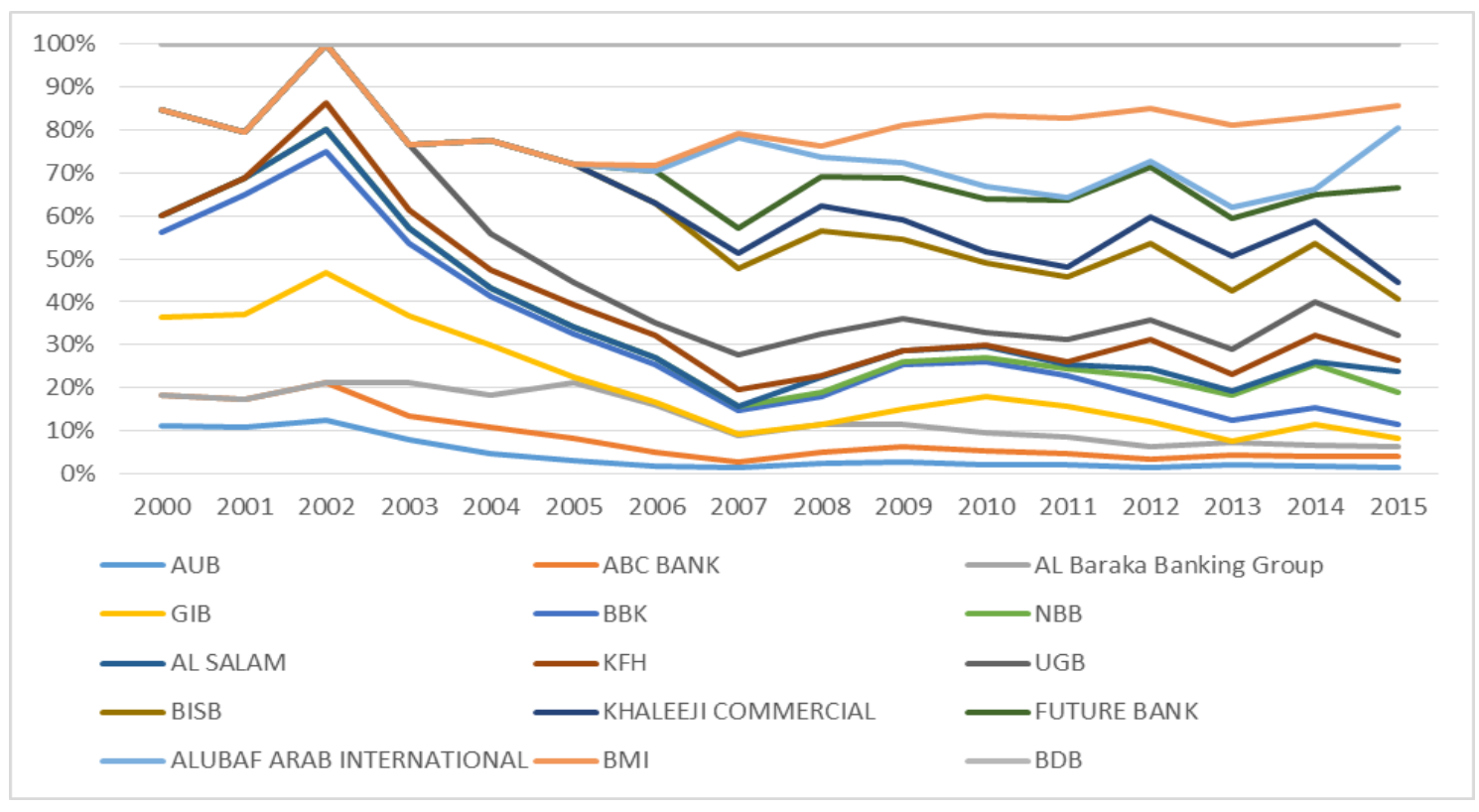

Fig.1 NPLs to Gross loans - Bahrain Source: Bank Scope Database

The NPL ratio for banks in Saudi Arabia was moderate in 2000 and 2001 as can be seen in figure 2. It slightly increased in the coming years and had sudden decrease in 2005. But again it started to increase and reached the peak in 2007. It slowly and gradually came down and started to rise again in 2010 and 2011. Then it became steady in 2012 till 2015.

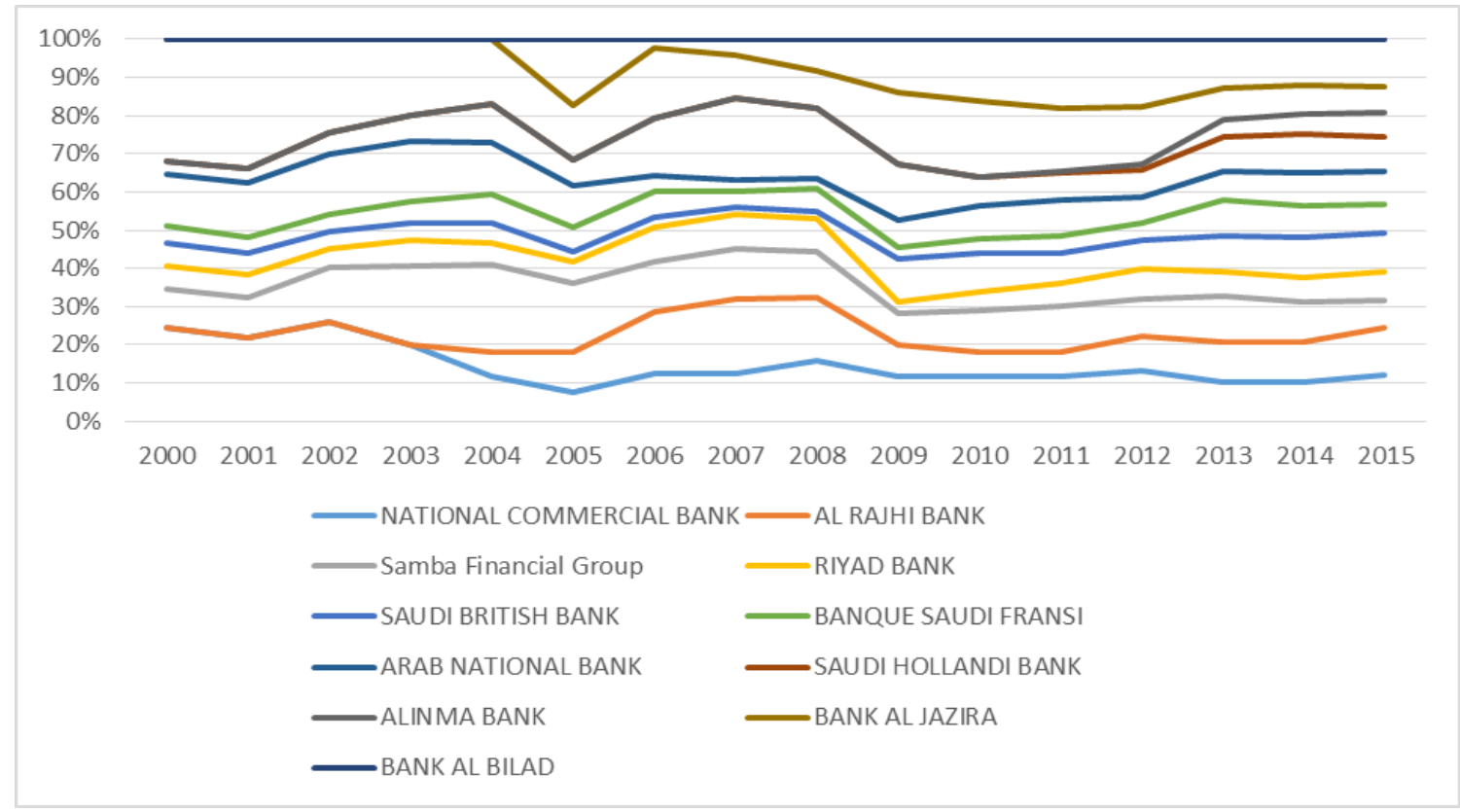

Fig.2 NPLs to Gross loans - Saudi Arabia Source: Bank Scope Database 


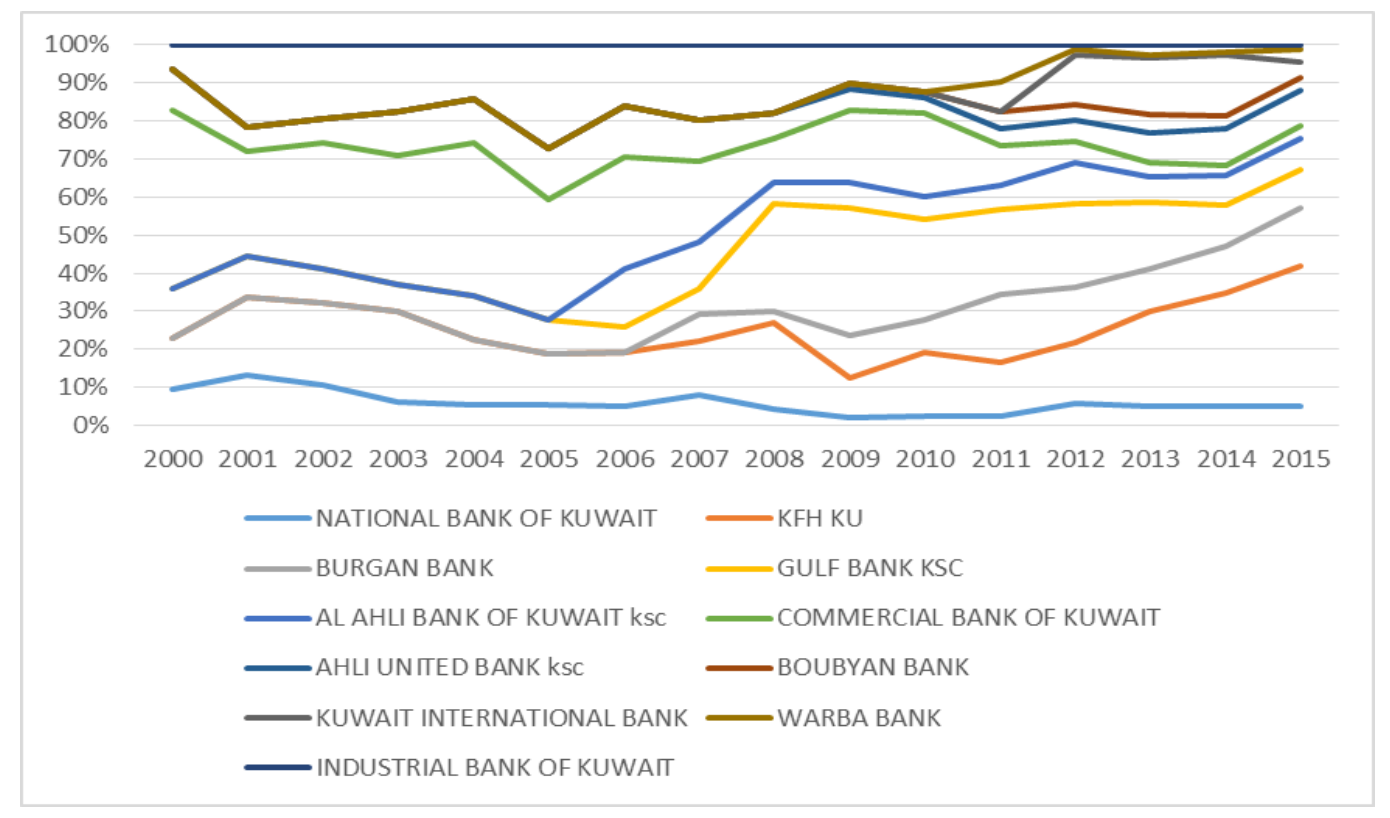

Fig.3 NPLs to Gross loans - Kuwait Source: Bank Scope Database

As shown in figure 3, the NPL ratio for Kuwaiti banks was low in early 2000s for most of the banks. Then it became somewhat steady. In 2005, NPL ratio declined for most of the banks. But it started to increase sharply from 2007 till 2008. A little decrease was noted in 2009 but then it started to increase again and had high NPLs in the year 2015.

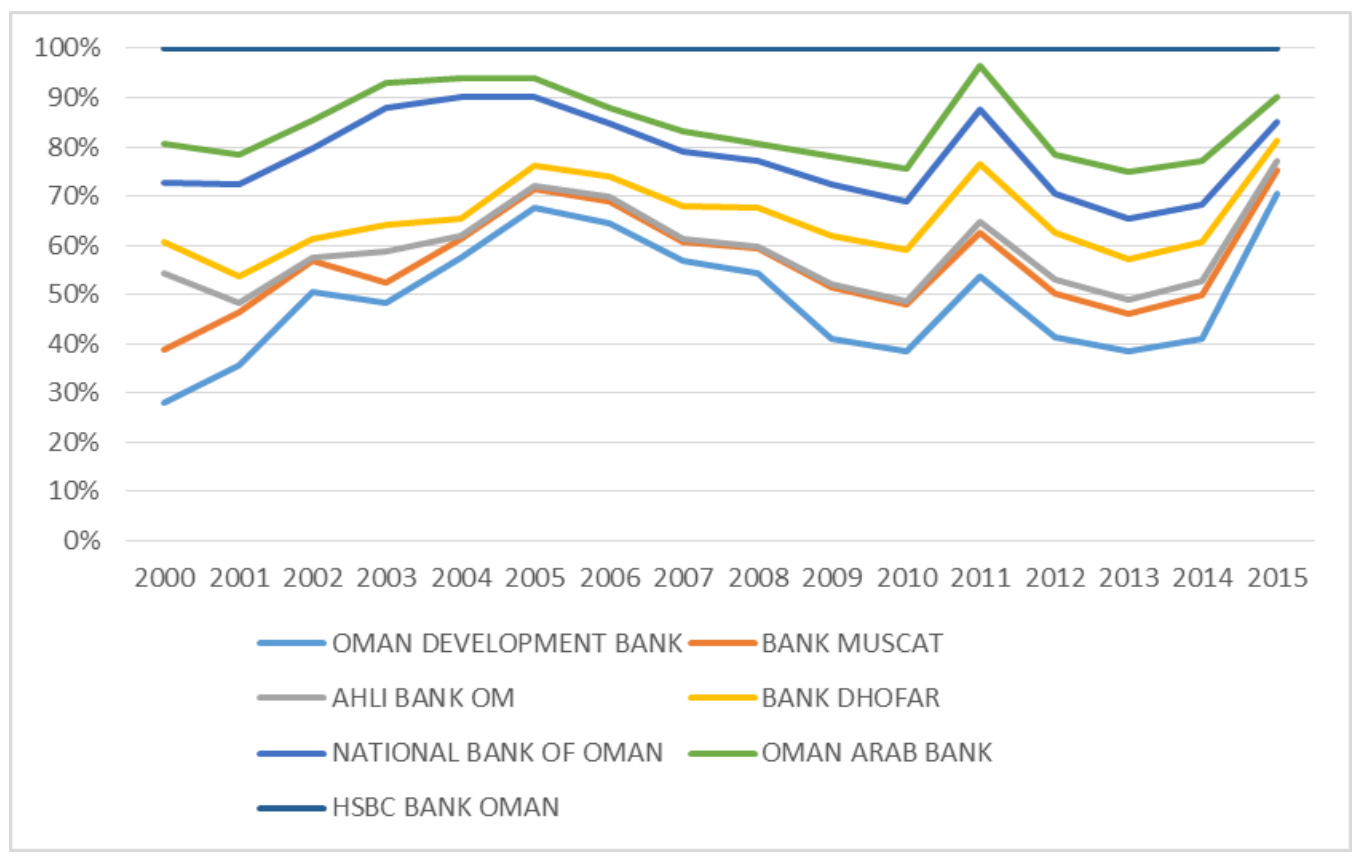

Fig.4 NPLs to Gross loans - Oman Source: Bank Scope Database 
It can be noted from figure 4, the NPL ratio for Omani banks started to increase from the year 2001 reaching the peak in 2005. Thereafter it started to decrease till the year 2009. Whereas in 2010, a sudden increase was observed reaching the highest point in the year 2011 and thereafter it started to decrease soon after. But increased again the year 2014 and remained high in the year 2015.

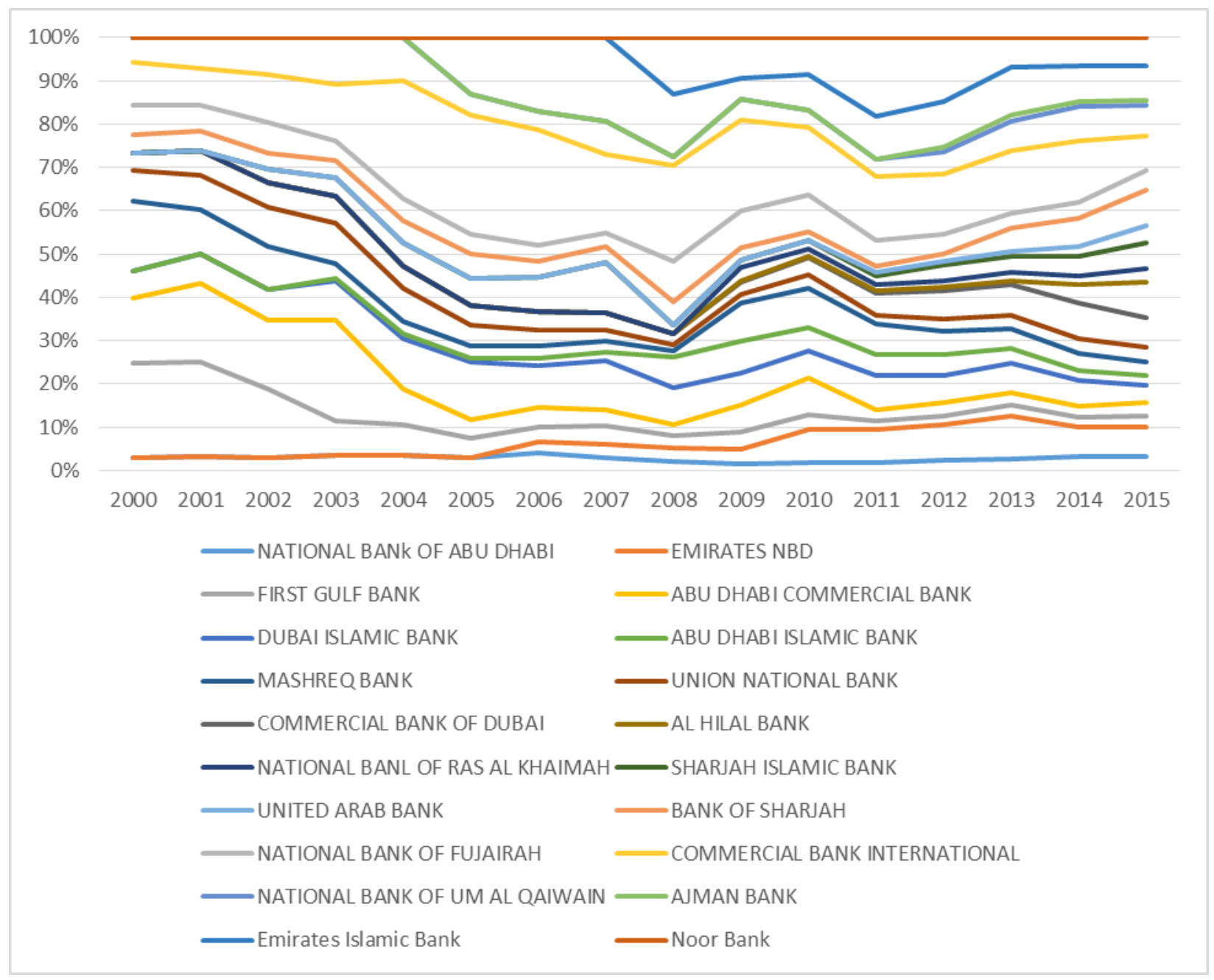

Fig.5 NPLs to Gross loans - UAE Source: Bank Scope Database

As can be seen from the figure 5 given above, the NPL ratio for UAE banks started coming down in the year 2001 but increased in the year 2007, for a few banks it decreased in 2008 but then during the post crisis period, the NPL ratio increased for all the banks and remained high till the year 2015. 
ENTREPRENEURSHIP AND SUSTAINABILITY ISSUES

ISSN 2345-0282 (online) http://jssidoi.org/jesi/

2019 Volume 6 Number 4 (June)

http://doi.org/10.9770/jesi.2019.6.4(..)

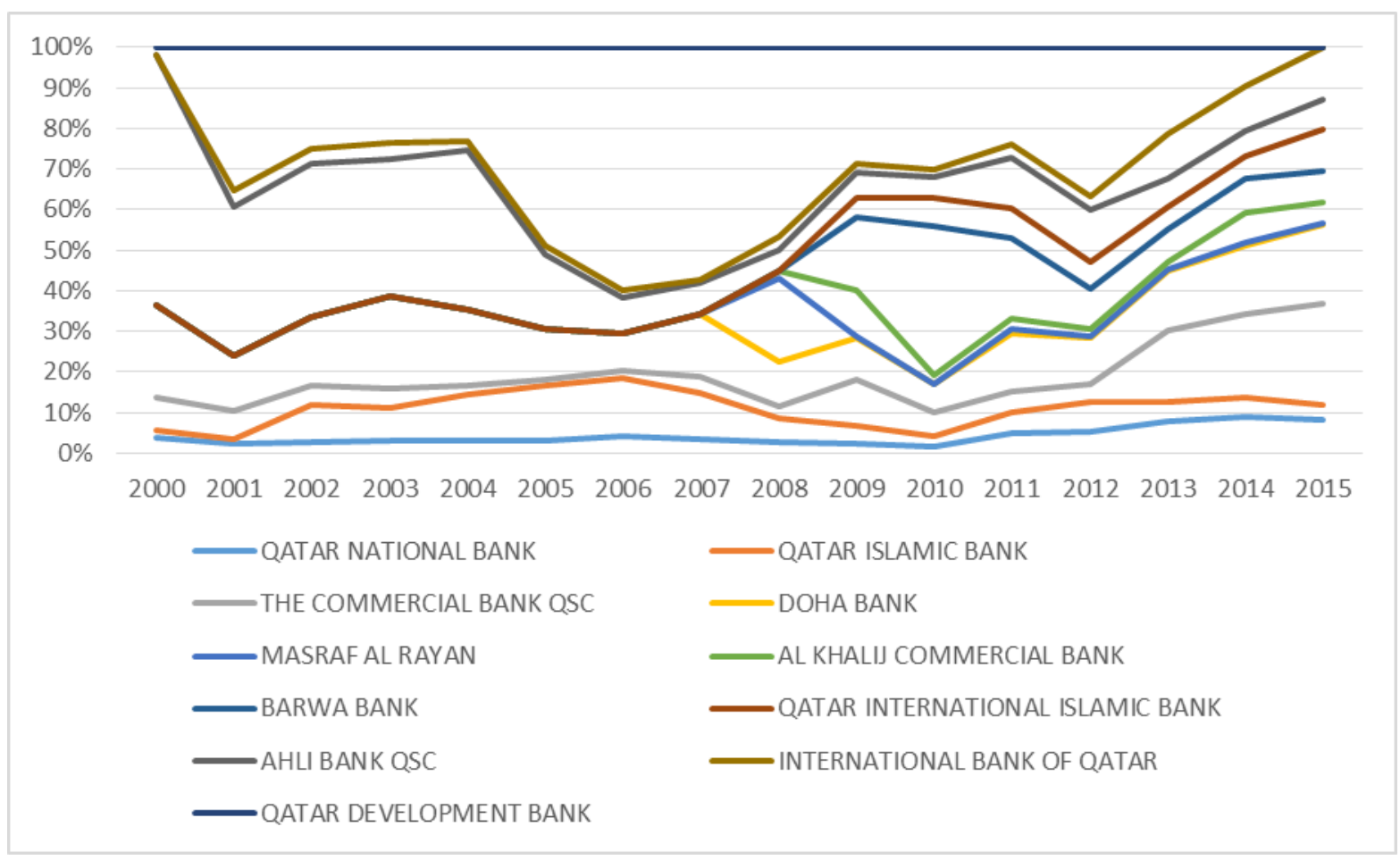

Fig.6 NPLs to Gross loans - Qatar

Source: Bank Scope Database

From the figure 6, for Qatar the NPL ratio for some commercial banks was quite high in 2000. It decreased suddenly in the year 2001. It started to increase from 2001 and slight fluctuations were seen till year 2009. In post crisis period, the NPL ratio increased for most of the commercial banks which decreased in 2012 but then later rose again from 2012 and remained high till 2015.

\section{Data, Theoretical Framework and Methodology}

\subsection{Data}

This study investigates and explains the relationship between NPLs and its determinants. Explanatory and quantitative research approach have been used in accordance with empirical literature. The study covers 66 commercial banks whether Islamic or conventional in GCC region using purposive sampling technique. These banks were selected on the basis that they operated before, during and after the global financial crises and according to the data availability. The list of the banks can be referred to in Appendix I.

The secondary source of data was used for this study which was efficient. The cross-country bank level data was collected from the financial database Bank Scope for 6 countries in the GCC region for the period from 2009 to 2015. Data for the internal factors, i.e. bank specific factors, were obtained from it. Moreover, the database of International Monetary Fund's World Economic Outlook was also considered for external, macroeconomic factors.

To determine the factors affecting NPLs in the GCC countries and thoroughly investigate the empirical relationship between these factors and NPLs the following variables were taken into consideration because from the previous studies and literature such as the work of Boudriga et al. (2009), Espinoza and Prasad (2010), Ali and Daly (2010), Bofondi and Ropele (2011), Bock and Demyanets (2012), Klein (2013), Makri et al. (2014), Abid et 
ENTREPRENEURSHIP AND SUSTAINABILITY ISSUES

ISSN 2345-0282 (online) http://jssidoi.org/jesi/

2019 Volume 6 Number 4 (June)

http://doi.org/10.9770/jesi.2019.6.4(..)

al. (2014), Dhar and Bakshi (2015) to name a few, which are the among the most important variables affecting the NPLs.

For the purpose of this study, as defined in the literature, non-performing loans are the bad loans which are outstanding for a long time as per the contract of loan. According to Tesfaye (2012), any loan which is not repaid timely in accordance to the loan agreement is known as non-performing.

Most of the independent variables are taken from previous studies.

Return on Average Assets (ROAA) represents efficiency in using assets. It shows how much net income is produced out of assets. The higher the ratio, the better. High ROAA may be because of high lending rates of banks and fees that increase bank profitability and size. Different studies concluded different results. Makri et al. (2014) found positive relationship between NPL ROAA. Whereas Messai and Jouini (2013) found negative relationship between them, suggesting that fall in profitability ratio leads to risky activities taken by banks which raise NPL level.

Return on Average Equity (ROAE) represents return rate from equity invested in banks. It shows how much net income is generated with amount invested by shareholders. Makri et al. (2014) found negative relationship between ROAE and NPL.

The size of the banks is represented by the banks' assets. Larger size may mean high profitability, efficiency and diversification. However, the large growth of the bank may have opposite effect: less efficiency and high risk.

Efficiency is used for quality of management in the literature. Management quality is crucial in the success of the firms in the long run. If the quality is poor, it will affect banks credit decisions and monitoring borrowers. It is calculated by cost to income ratio. If the ratio is high then it means operating efficiency is low thus leading to high level of NPL.

The increase in the price level is called inflation resulting decline in purchasing power of money. From literature review, it is noted that as inflation increases, the cost of borrowing becomes expensive and hence having adverse effect on quality of loan portfolio.

The GDP annual growth percentage represents the ratio indicating all final goods and services produced in a year. It shows the health of economy. If the economy is doing poorly, then firms will have lower profits.

Table 2 Bank Specific Factors

$\begin{array}{ll}\text { Bank Level Factors } & \text { Definitions } \\ \text { ROAA } & \text { Net income/ average assets } \\ \text { ROAE } & \text { Net income/ average equity } \\ \text { SIZE } & \text { Natural Log of total assets } \\ \text { COSTEFF } & \text { Cost to income ratio }\end{array}$

Table 3 Macroeconomic Factors

\begin{tabular}{ll}
\hline Macroeconomic Factors & Definitions \\
INFLR & Inflation rate, GDP deflator \% \\
GDP & Gross domestic product annual growth \% \\
\hline
\end{tabular}

Due to different legislations, rules and policies NPLs can be different. In GCC region, non-performing loans are the loans which are not paid for ninety days or more. As the dependent variable, NPL ratio is measured by 
nonperforming loans to gross loans. The dependent variable and explanatory variables covers the time period from the year 2009 to year 2015. Total of 462 observations were collected.

Table 4 Summary Statistics of NPL ratio

\begin{tabular}{ll}
\hline Mean & 5.214113 \\
Maximum & 30.330 \\
Minimum & 0 \\
Std. Dev. & 5.605544 \\
Jarque-Bera & 664.8954 \\
Probability & 0 \\
Observations & 462 \\
\end{tabular}

\subsection{Theoretical Framework}

The study of Berger and DeYoung (1997) has important place in investigating sufficient factors of NPL ratio. The bad management hypothesis is mentioned is relevant in this context. According to this hypothesis, NPL ratio is affected by managerial quality. This interaction has been examined with the model given below.

$$
N P L_{i t}=a_{0}+a_{i} B_{i, t}+a_{i} M_{i, t}+\varepsilon_{i, t}
$$

In this model, NPL symbolizes non-performing loans that are the bad loans which are outstanding for a long time as per the contract of loan. B symbolizes bad management factors which are return on asset and return on equity in this study. The last one, M symbolizes macroeconomic factors. Furthermore, the asset size hypothesis which explains the NPL ratio, similar to the bad management hypothesis, was introduced by Salas and Saurina (2002). According to this theory, the size of the banks negatively affects the NPL ratio. The model based on this theory is given below.

$$
N P L_{i t}=a_{0}+a_{i} S_{i, t}+a_{i} M_{i, t}+\varepsilon_{i, t}
$$

In model 2, only $\mathrm{S}$ factor is different from the model 1 and this factor symbolizes asset size. It is assumed that the increase in costs in the bad luck hypothesis affects the NPL.

$$
N P L_{i t}=a_{0}+a_{i} C_{i, t}+a_{i} M_{i, t}+\varepsilon_{i, t}
$$

$\mathrm{C}$ represents cost efficiency in the bad luck hypothesis. In addition, the following model can be established by combining the hypothesis of bad management, bad luck and asset size.

$$
N P L_{i t}=a_{0}+a_{i} B_{i, t}+a_{i} C_{i, t}+a_{i} S_{i, t}+a_{i} M_{i, t}+\varepsilon_{i, t}
$$

\subsection{Methodology}

This study used both explanatory and econometrics analysis based on panel data from the year 2009 to 2015 to investigate the relationship between NPLs and its determining factors of commercial banks in GCC region. Data was analyzed by GMM (Generalized Method of Moments) regression. 
Holtz-Eakin, Newey and Rosen (1988), Arellano and Bond (1991), Arellano and Bover (1995) and Blundell and Bond (1998) developed model GMM-system approach that solves the inwardness problem and can be applied to samples with $\mathrm{T}<\mathrm{N}$ characteristics. This method is basically instrumental variable method. Variables thought to carry the problem of endogenous are not used. Instead of using endogenous variables, instrumental variables with similar moment properties are generated and instrumental variables are used in the regression model. The GMM beta estimator for the mentioned model is expressed in the following equation.

$$
\hat{\beta}_{G M M}=\left(X^{`} Z W Z \backslash X\right)^{-1} X^{`} Z W Z^{`} y
$$

In this model, $X, y, Z$, symbolize the independent variable matrix, dependent variable matrix and the symmetric weight matrix, respectively.

\section{Findings and Analysis}

To study and analyze the effects of macroeconomic and bank specific factors on non-performing loans as well as to know the significance of the model being estimated and the significance of each independent variable affecting NPL ratio, GMM system approach was run.

Table 5 GMM Two Step System Approach Results

\begin{tabular}{|c|c|c|c|c|}
\hline Variables & Model 1 & Model 2 & Model 3 & Model 4 \\
\hline NPL(-1) & $\begin{array}{c}.8553142 \\
(0.000)\end{array}$ & $\begin{array}{c}.8721844 \\
(0.000)\end{array}$ & $\begin{array}{c}.8697022 \\
(0.000)\end{array}$ & $\begin{array}{c}.7931867 \\
(0.000)\end{array}$ \\
\hline ROAA & $\begin{array}{c}-1.45891 \\
(0.000)\end{array}$ & & & $\begin{array}{c}-1.37365 \\
(0.000)\end{array}$ \\
\hline ROAE & $\begin{array}{c}.0170012 \\
(0.167)\end{array}$ & & & $\begin{array}{c}.0101861 \\
(0.165)\end{array}$ \\
\hline SIZE & & $\begin{array}{c}-1.04316 \\
(0.000)\end{array}$ & & $\begin{array}{c}-.650243 \\
(0.000)\end{array}$ \\
\hline COSTEFF & & & $\begin{array}{c}.0691976 \\
(0.000)\end{array}$ & $\begin{array}{c}.0023734 \\
(0.386)\end{array}$ \\
\hline GDP & $\begin{array}{c}.0406736( \\
0.000)\end{array}$ & $\begin{array}{c}.0059461 \\
(0.142)\end{array}$ & $\begin{array}{c}.0063091 \\
(0.159)\end{array}$ & $\begin{array}{c}.049294 \\
(0.000)\end{array}$ \\
\hline INF & $\begin{array}{c}.0049897 \\
(0.003)\end{array}$ & $\begin{array}{c}-.008355 \\
(0.000)\end{array}$ & $\begin{array}{c}.0035226 \\
(0.013)\end{array}$ & $\begin{array}{c}-.001866 \\
(0.131)\end{array}$ \\
\hline CONSTANT & $\begin{array}{c}2.471483 \\
(0.000)\end{array}$ & $\begin{array}{c}10.42978 \\
(0.000)\end{array}$ & $\begin{array}{c}-2.43236 \\
(0.000)\end{array}$ & $\begin{array}{c}8.70349 \\
(0.000)\end{array}$ \\
\hline Wald Test & $\begin{array}{c}90140.98 \\
(0.000)\end{array}$ & $\begin{array}{c}70735.98 \\
(0.000)\end{array}$ & $\begin{array}{c}137200.1 \\
(0.000)\end{array}$ & $\begin{array}{c}942302.7 \\
(0.000)\end{array}$ \\
\hline Sargan Test & $\begin{array}{c}54.66178 \\
(0.4112)\end{array}$ & $\begin{array}{c}54.10811 \\
(0.4319)\end{array}$ & $\begin{array}{c}55.37874 \\
(0.3850)\end{array}$ & $\begin{array}{r}62.45677 \\
(0.8058)\end{array}$ \\
\hline $\operatorname{AR}(2)$ & $\begin{array}{c}.31045 \\
(0.7562)\end{array}$ & $\begin{array}{r}.33794 \\
(0.7354)\end{array}$ & $\begin{array}{c}.16798 \\
(0.8666)\end{array}$ & $\begin{array}{c}.25224 \\
(0.8009)\end{array}$ \\
\hline
\end{tabular}

Notes: P-values are reported in parenthesis. 


\section{ENTREPRENEURSHIP AND SUSTAINABILITY ISSUES}

ISSN 2345-0282 (online) http://jssidoi.org/jesi/

2019 Volume 6 Number 4 (June)

http://doi.org/10.9770/jesi.2019.6.4(..)

Models 1, 2, 3 and 4 represent bad management, asset size, bad luck and combined theories, respectively. All the models are statistically significant and it can be seen that there is also no endogeneity problem with the results of the Sargan test. No auto correlation problem was found in the models. Only variables ROAA and SIZE are statistically significant in all of the models in which they are used. Also, ROAA and SIZE are significantly negatively related to NPLs. Inflation only differs from model to model in terms of positive and negative effects.

\section{Conclusions}

The purpose of this study was to examine the determinants of NPLs in GCC region for a period from 2009 to 2015. The data was analyzed by using two step GMM approach to know the relationship that exists between dependent and independent variables in the models.

The trend analysis of NPL ratio for GCC countries showed that NPLs rate was more in the early 2000s which slowly and gradually decreased and then suddenly increased in the post global financial crisis period and remained high till the year 2015. Four different models employed as a result of the examination of the theories were used to observe the determinants of NPLs. According to the findings of the model generated from the bad management hypothesis, bank profitability measured by ROAA has significant and negative effect on NPLs. In the same model, macroeconomic factors have statistically significant and positive effect on NPLs. Statistically significant and negative effects of bank size and inflation were observed in the model which regarded asset size of banks. In the third model, the bad luck hypothesis output showed that COSTEFF is significantly negatively related to NPLs. The combined model was created using the variables in all other models. In combined model, bank profitability measured by ROAA has significant and negative effect on NPLs. This suggests that banks in GCC region tend more to increase return by using their assets and effectively managing the funds contributed by the shareholders respectively. The cost to income ratio is positively related to NPLs meaning that more cost efficiency will lead to less NPLs. The inflation rate is negatively related to NPLs. This suggests that rise in the inflation will lead to less borrowing and hence less NPLs.

Based on the findings and results, it is recommended that NPLs are a serious issue which should be given due attention. Management of the bank should carefully assess the asset quality, represented by NPLs, which influences the bank performance and financial stability of the economy. The basic function of banks is to accept deposits and lend those deposits not only for short time but also for long time such as for government, businesses and housing etc. Delay in loan repayment will make it more difficult in obtaining further credit. The management should efficiently utilize the current assets because short term loans and advances are runnable meaning that anytime they can be demanded back by the creditors. Bank management has to monitor credit lending policies and do better client profiling not just looking at the financial condition but also their consumption behaviour. Bank management should also provide consultation services to borrowers in order to help them using loans wisely and communicate with them regularly in order to know their repayment ability or any change therein.

Bank management should implement efficient receivable management strategy to collect from borrowers on time. This will also help depositors and investors in boosting their confidence in banking industry and therefore improving efficient resource distribution procedure, which will also assist in sustainable growth of economic activities of the countries. 


\section{ENTREPRENEURSHIP AND SUSTAINABILITY ISSUES}

ISSN 2345-0282 (online) http://jssidoi.org/jesi/

2019 Volume 6 Number 4 (June)

http://doi.org/10.9770/jesi.2019.6.4(..)

\section{References}

Abid, L., Ouertani, M. \& Zouari-Ghorbel, S. 2014. Macroeconomic and Bank-Specific Determinants of Household's Non-Performing Loans in Tunisia: A Dynamic Panel Data, Procedia Economics and Finance, 13: 58-68. https://doi.org/10.1016/S2212-5671(14)00430-4

Aktan, B., Turen, S., Tvaronaviciene, M., Celik, S., Alsadeh, H.A. 2018. Corporate governance and performance of the financial firms in Bahrain, Polish Journal of Management Studies 17(1): 39-58. https://doi.org/10.17512/pjms.2018.17.1.04

Ahmad, N. \& Ariff, M. 2007. Multi-country study of bank credit risk determinants, International Journal of Banking and Finance 5(1): 135-152, Retrieved from http://ijbf.uum.edu.my/images/pdf/5no1ijbf/6ijbf51.pdf

Alhassan, A., Brobbey, F. \& Asamoah, M. 2013. Does Asset Quality Persist on Bank Lending Behavior? Empirical Evidence from Ghana, Global Journal of Management and Business Research Finance 13(4): 1-8, Retrieved from https://core.ac.uk/download/pdf/19903462.pdf

Alhassan, A., Keyreboah-Coleman, A. \& Andoh, C. 2014. Asset Quality in a Crisis Period: An Empirical examination of Ghanaian Banks, Review of Development Finance 4(1): 50-62. https://doi.org/10.1016/j.rdf.2014.03.001

Ali, A. \& Daly, K. 2010. Macroeconomic determinants of credit risk: recent evidence from a cross country study, International Review of Financial Analysis 19(3): 165-171. https://doi.org/10.1016/j.irfa.2010.03.001

Ashraf, M., Masood, O., Tvaronavičienė, M., Bora Aktan, B., Garškaitė-Milvydienė, K., Lace, N. 2019. Factors Affecting Development Patterns: Econometric investigation of Japan equity market, Economic Research-Ekonomska Istraživanja 32(1) https://doi.org/10.1080/1331677X.2018.1551147

Athanasoglou, P., Brissimis, S. \& Delis, M. 2009. Bank specific, Industry specific and macroeconomic determinants of bank profitability, Journal of International Financial Markets, Institutions and Money 18(2): 121-136. https://doi.org/10.1016/j.intfin.2006.07.001

Aysan, A., Ozturk H., Polat A \& Saltoğlu, B. 2016. Macroeconomic Drivers of Loan Quality in Turkey, Emerging Markets Finance and Trade 52(1): 98-109. https://www.tandfonline.com/doi/abs/10.1080/1540496X.2016.1105688

Arellano, M. \& Bond, S. 1991. Some Tests of Specification for Panel Data: Monte Carlo Evidence and an Application to Employment Equations, The Review of Economic Studies 58(2): 277-297, R etrieved from https://academic.oup.com/restud/articleabstract/58/2/277/1563354

Arellano, M. \& Bover, O. 1995. Another Look at the Instrumental Variable Estimation of Error-Components Models, Journal of Econometrics 68(1): 29-51. https://doi.org/10.1016/0304-4076(94)01642-D

Beck, T., Demirgüç-Kunt, A., \& Levine, R. 2006. Bank concentration, competition, and crises: First results, Journal of Banking and Finance 30(5): 1581-1603. https://doi.org/10.1016/j.jbankfin.2005.05.010

Berger, A. \& DeYoung, R. 1997. Problem Loans and Cost Efficiency in Commercial Banks, Journal of Banking and Finance 21(7): 849870, Retrieved from https://www.sciencedirect.com/science/article/pii/S0378426697000034

Blundell, R. \& Bond, S. 1998. Initial Conditions and Moment Restrictions in Dynamic Panel Data Models, Journal of Econometrics 87(1): 115-143. https://doi.org/10.1016/S0304-4076(98)00009-8

Bock, Reinout \& Demyanets, A. 2012. Bank Asset Quality in Emerging Markets: Determinants and Spillovers, IMF Working Paper 12/71, Retrieved from https://www.imf.org/ /media/Websites/IMF/imported-full-text-pdf/external/pubs/ft/wp/2012/_wp1271.ashx

Bofondi, M. \& Ropele, T. 2011. Macroeconomic Determinants of Bad Loans: Evidence from Italian Banks, Bank of Italay Questioni di Economia e Finanza (Occasional Papers) No 89, Retrieved from https://www.bancaditalia.it/pubblicazioni/qef/20110089/index.html?com.dotmarketing.htmlpage.language $=1$

Boudriga, A., Taktak, N. \& Jellouli, S. 2009. Banking supervision and nonperforming loans: a cross country analysis, Journal of Financial Economic Policy 1(4): 286-318, Retrieved from https://econpapers.repec.org/RePEc:eme:jfeppp:v:1:y:2009:i:4:p:286-318

Chaibi, H. \& Ftiti, Z. 2015. Credit risk determinants: Evidence from a cross-country study, Research in International Business and Finance 33(C): 1-16. https://doi.org/10.1016/j.ribaf.2014.06.001 


\section{ENTREPRENEURSHIP AND SUSTAINABILITY ISSUES}

ISSN 2345-0282 (online) http://jssidoi.org/jesi/

2019 Volume 6 Number 4 (June)

http://doi.org/10.9770/jesi.2019.6.4(..)

Dash, M. \& Kabra, G. 2010. The determinants of non-performing assets in Indian commercial bank: An Econometric study, Middle

Eastern Finance and Economics 7: 94-106, Retrieved from

https://www.researchgate.net/publication/258090738_The_Determinants_of_Non-

Performing_Assets_in_Indian_Commercial_Bank_An_Econometric_Study

Demirgüç-Kunt, A. \& Huizinga, H. 1999. Determinants of Commercial Bank Interest Margins and Profitability: Some International Evidence, The World Bank Economic Review 13(2): 379-408. https://doi.org/10.1093/wber/13.2.379

Demirgüç-Kunt, A. \& Detragiache, E. 2002. Does deposit insurance increase banking system stability? An empirical investigation, Journal of Monetary Economics 49(7): 1373-1406. https://doi.org/10.1016/S0304-3932(02)00171-X

Dietrich, A. \& Wanzenried, G. 2011. Determinants of bank profitability before and during the crisis: Evidence from Switzerland, Journal of International Financial Markets, Institutions and Money 21(3): 307-327. https://doi.org/10.1016/j.intfin.2010.11.002

Dhar, S. \& Bakshi, A. 2015. Determinants of loan losses of Indian Banks: A panel study, Journal of Asia Business Studies 9(1): 17-32, Retrieved from https://www.emeraldinsight.com/doi/10.1108/JABS-04-2012-0017

Ezeoha, A. 2011. Banking consolidation, credit crisis and asset quality in a fragile banking system: Some evidence from Nigerian data, Journal of Financial Regulation and Compliance 19(1): 33-44, Retrieved from https://www.emeraldinsight.com/doi/10.1108/13581981111106158

Espinoza, R. \& Prasad, A. 2010. Nonperforming Loans in the GCC Banking System and their Macroeconomic Effects, IMF Working Paper, Middle East and Central Asia Department (WP/10/224), Retrieved from

https://www.imf.org/external/pubs/ft/wp/2010/wp10224.pdf

Fakhry, B., Aktan, B., Masood, O.; Tvaronavičienė, M., Celik, S. 2018. The Impact of a recent natural disaster on the Japanese financial markets: empirical evidenece, Journal of Competitiveness 10(2): 56-71 https://doi.org/10.7441/joc.2018.02.04

Fofack, H. 2005. Non-performing loans in sub-Saharan Africa: Causal Analysis and Macroeconomic Implications, World Bank Policy Research Working Paper Nos. 3769, Retrieved from http://documents.worldbank.org/curated/en/446961468104639856/Nonperformingloans-in-Sub-Saharan-Africa-causal-analysis-and-macroeconomic-implications

Gerlach, S., Peng W. \& Shu, C. 2005. Macroeconomic conditions and banking performance in Hong Kong SAR: A panel data study, Bank for International Settlements, Basel. BIS papers No. 22, Retrieved from https://www.bis.org/publ/bppdf/bispap22x.pdf

Godlewski, C. 2005. Capital Regulation and Credit Risk Taking: Empirical Evidence from Banks in Emerging Market Economies, Journal of Banking Regulation 6(2): 128-145, Retrieved from

https://www.researchgate.net/publication/23743752_Capital_Regulation_and_Credit_Risk_Taking_Empirical_Evidence_from_Banks_in_ Emerging_Market_Economies

IMF, Annual report 2005. Retrieved from

http://www.imf.org/en/Publications/AREB/Issues/2016/12/31/Annual-Report-of-the-Executive-Board-for-the-Financial-Year-Ended-April$\underline{30-2005}$

Islamoğlu, M. 2015. The Effect of Macroeconomic Variables on Non-performing Loan Ratio of Publicly Traded Banks in Turkey, WSEAS Transactions on Business and Economics 12: 12-20, Retrieved from http://www.wseas.org/multimedia/journals/economics/2015/a045707290.pdf

Jiménez, G., Salas, V. \& Saurina, J. 2006. Determinants of collateral, Journal of Financial Economics 81(2): 255-281, Retrieved from https://www.sciencedirect.com/science/article/pii/S0304405X05002369

Klein, N. 2013. Non-Performing Loans in CESEE: Determinants and Impact on Macroeconomic Performance, IMF Working Paper, European Department, (P/13/72), Retrieved from https://www.imf.org/en/Publications/WP/Issues/2016/12/31/Non-Performing-Loans-inCESEE-Determinants-and-Impact-on-Macroeconomic-Performance-40413

Louzis, D., Vouldis, A. \& Metaxas, V. 2012. Macroeconomic and bank-specific determinants of non-performing loans in Greece: A comparative study of mortgage, business and consumer loan portfolios, Journal of Banking and Finance 36(4): 1012-1027.

https://doi.org/10.1016/j.jbankfin.2011.10.012 


\section{ENTREPRENEURSHIP AND SUSTAINABILITY ISSUES}

ISSN 2345-0282 (online) http://jssidoi.org/jesi/

2019 Volume 6 Number 4 (June)

http://doi.org/10.9770/jesi.2019.6.4(..)

Macit, F. 2012. What Determines the Nonperforming Loans Ratio: Evidence from Turkish Commercial Banks, CEA Journal of Economics 7(1): 33-41, Retrieved from https://journal.cea.org.mk/index.php/ceajournal/article/view/108

Mahmudi, S. 2013. Correlation between Growth Rate and Non Performing Retail Loans in the Republic of Macedonia, International Journal of Academic Research in Accounting, Finance and Management Sciences 3(3): 133-138, Retrieved from http://hrmars.com/hrmars_papers/Article_16_Correlation_between_Growth_Rate.pdf

Makri, V., Tsagkanos, A. \& Bellas, A. 2014. Determinants of Nonperforming Loans: The Case of Eurozone, Panoeconomicus 61(2): 193206, Retrieved from https://panoeconomicus.org/index.php/jorunal/article/view/72

Masood, O.; Tvaronavičiené, M.; Javaria, K. 2019. Impact of oil prices on stock return: evidence from G7 countries, Insights into Regional Development 1(2): 129-137. https://doi.org/10.9770/ird.2019.1.2(4)

Messai, A. \& Jouini, F. 2013. Micro and Macro Determinants of Non-Performing Loans, International Journal of Economics and Financial Issues 3(4): 852-860, Retrieved from http://www.econjournals.com/index.php/ijefi/article/view/517

Pesaran, M., Shin, Y. \& Smith, R. 2001. Bounds testing approaches to the analysis of level relationships, Journal of Applied Econometrics 16(3): 289-326, Retrieved from https://onlinelibrary.wiley.com/doi/pdf/10.1002/jae.616

Quagliariello M. 2007. Bank's riskiness over the business cycle: A panel analysis on Italian intermediaries, Applied Financial Economics, 17(2): 119-138, Retrieved from https://www.tandfonline.com/doi/full/10.1080/09603100500486501

Rossi, S., Schwaiger M. \& Winkler, G. 2008. Linking Managerial Behaviour to Cost and Profit Efficiency in the Banking Sectors of Central and Eastern European Countries, Kredit und Capital 41(4): 598-629, Retrieved from https://ideas.repec.org/a/kuk/journl/v41y2008i4p589-629.html

Salas, V. \& Saurina, J. 2002. Credit risk in two institutional regimes: Spanish commercial and savings banks, Journal of Financial Services Research 22(3): 203-224, Retrieved from https://link.springer.com/article/10.1023/A:1019781109676

Swamy, V. 2012. Impact of Macroeconomic and Endogenous Factors on Nonperforming Bank Assets, International Journal of Banking and Finance 9(1): 27-47, Retrieved from https://mpra.ub.uni-muenchen.de/49600/1/Non-performing\%20bank\%20assets.pdf

Tesfaye, T. 2012. Determinants of Banks Liquidity and Their Impact on Financial Performance: Empirical Study on Commercial banks in Ethiopia, Published thesis (MSc). Addis Ababa University, Ethiopia, Retrieved from

http://etd.aau.edu.et/handle/123456789/14989?show=full

Vatansever, M. \& Hepşen, A. 2013. Determining Impacts on Non-performing loan ratio in Turkey, Journal of Finance and Investment Analysis 2(4): 119-129, Retrieved from http://www.scienpress.com/Upload/JFIA\%2FVol\%202_4_7.pdf

Williams, J. 2004. Determining management behavior in European banking, Journal of Banking and Finance 28(10): 2427-2460. https://doi.org/10.1016/j.jbankfin.2003.09.010

Zribi, N. \& Boujelbène, Y. 2011. The factors influencing bank credit risk: The case of Tunisia, Journal of Accounting and Taxation 3(4): 70-78, Retrieved from http://academicjournals.org/journal/JAT/article-full-text-pdf/C53D91B795

\section{Appendix}

List of Banks:

\begin{tabular}{|c|c|c|c|}
\hline Country & Bank Name & Country & Bank Name \\
\hline Bahrain & Ahli United bank & Oman & Bank Muscat \\
\hline Bahrain & Arab Banking Corporation & Oman & Ahli Bank OM \\
\hline Bahrain & Al Baraka Banking Group & Oman & Bank Dhofar \\
\hline Bahrain & Gulf International Bank & Oman & National Bank of Oman \\
\hline Bahrain & BBK & Oman & Oman Arab Bank \\
\hline
\end{tabular}




\begin{tabular}{|c|c|c|c|}
\hline Bahrain & National Bank of Bahrain & Oman & HSBC Bank Oman \\
\hline Bahrain & Al Salam Bank & UAE & National Bank of Abu Dhabi \\
\hline Bahrain & Kuwait Finance House & UAE & Emirates NBD \\
\hline Bahrain & United Gulf Bank & UAE & First Gulf Bank \\
\hline Bahrain & Bahrain Islamic Bank & UAE & Abu Dhabi Commercial Bank \\
\hline Bahrain & Khaleeji Commercial Bank & UAE & Dubai Islamic Bank \\
\hline Bahrain & Future Bank & UAE & Abu Dhabi Islamic Bank \\
\hline Bahrain & Alubaf Arab International Bank & UAE & Mashreq Bank \\
\hline Bahrain & BMI Bank & UAE & Union National Bank \\
\hline Bahrain & Bahrain Development Bank & UAE & Commercial Bank of Dubai \\
\hline Saudi Arabia & National Commercial Bank & UAE & Al Hilal Bank \\
\hline Saudi Arabia & Al Rajhi Bank & UAE & National Bank of Ras Al Khaimah \\
\hline Saudi Arabia & Samba Financial Group & UAE & Sharjah Islamic Bank \\
\hline Saudi Arabia & Riyadh Bank & UAE & United Arab Bank \\
\hline Saudi Arabia & Saudi British Bank & UAE & Bank of Sharjah \\
\hline Saudi Arabia & Banque Saudi Fransi & UAE & National Bank of Fujairah* \\
\hline Saudi Arabia & Arab National Bank & UAE & Commercial Bank International \\
\hline Saudi Arabia & Saudi Hollandi Bank & UAE & National Bank of Um Al Qaiwain* \\
\hline Saudi Arabia & Alinma Bank & UAE & Ajman Bank* \\
\hline Saudi Arabia & Bank Al Jazira & UAE & Emirates Islamic Bank \\
\hline Saudi Arabia & Bank Al Bilad & UAE & Noor Bank* \\
\hline Kuwait & National Bank of Kuwait & Qatar & Qatar National Bank \\
\hline Kuwait & Kuwait Finance House KU & Qatar & Qatar Islamic Bank \\
\hline Kuwait & Burgan Bank & Qatar & The Commercial Bank QSC \\
\hline Kuwait & Gulf Bank KSC & Qatar & Doha Bank \\
\hline Kuwait & Al Ahli Bank of Kuwait KSC & Qatar & Masraf Al Rayan \\
\hline Kuwait & Commercial Bank of Kuwait & Qatar & Al Khalijee Commercial Bank \\
\hline Kuwait & Ahli United Bank KSC & Qatar & Barwa Bank \\
\hline Kuwait & Boubyan Bank & Qatar & Qatar International Islamic Bank \\
\hline Kuwait & Kuwait International Bank* & Qatar & Ahli Bank QSC \\
\hline Kuwait & Warba Bank* & Qatar & Qatar Development Bank* \\
\hline Kuwait & Industrial Bank of Kuwait & Qatar & International Bank of Qatar \\
\hline Oman & Oman Development Bank* & & \\
\hline
\end{tabular}

*denotes extracted banks for empirical analysis. All banks were used for 


\section{ENTREPRENEURSHIP AND SUSTAINABILITY ISSUES}

ISSN 2345-0282 (online) http://jssidoi.org/jesi/

2019 Volume 6 Number 4 (June)

http://doi.org/10.9770/jesi.2019.6.4(..)

Short biographical note about the contributors:

Seref TUREN is an Associate Professor of Finance, College of Business Administration, University of Bahrain, Bahrain. He holds a PhD in finance from the University of Istanbul. His research interests include: Corporate Finance; Financial Institutions; Investment Analysis and Portfolio Management.

ORCID ID: $\underline{\text { http://orcid.org/0000-0003-1962-3286 }}$

Mohamed ABDULLA is currently working as head of department of Economics and Finance and assistant professor of economics at the Department of Economics and Finance, University of Bahrain. He obtained PhD in Economics from University of Stirling, UK. He has extensive teaching and research experience as well as extensive consultancy experience through his work at the Gulf Organization for Industrial Consulting in Qatar. Main Research Interests include International economics, Industrial Economics, Development Economics, Islamic Economics and Finance.

ORCID ID: http://orcid.org/0000-0003-1501-2453

Mohammad Omar FAROOQ is an Associate Professor with the Department of Economics and Finance at the University of Bahrain. He has a PhD from University of Tennessee, Knoxville, USA. He is an associate editor of International Journal of Islamic and Middle Eastern Finance and Management (Emerald). His research interests span economic develoment, Financial markets and institutions, History of Ecoomic Thought, Islamic economics and finance.

ORCID ID: http://orcid.org/0000-0002-4112-7222

Mohamed Sayed Abou ELSOUD holds Ph.D. in Economics from faculty of economics and political sciences, Cairo University. He is an associate professor of economics at Sadat Academy for Management sciences in Egypt, and currently works at University of Bahrain, College of Business Administration, Department of Economics and Finance. He specializes in economic policies, econometrics and nonparametric models. His research interests: Macroeconomic models, Economic development, applied economics and financial markets.

ORCID ID: http://orcid.org/0000-0003-3877-4784

Copyright (C) 2019 by author(s) and VsI Entrepreneurship and Sustainability Center

This work is licensed under the Creative Commons Attribution International License (CC BY).

http://creativecommons.org/licenses/by/4.0/

cc) (i) Open Access 